Euler, H. von, Hevesy, G. \& Solodkowska, S. (1948). Ark. Kemi Min. Geol. 26 A, 1.

Friedkin, M. \& Lehninger, A. L. (1949). J. biol. Chem. 177, 775.

Hammarsten, E. \& Hevesy, G. (1946). Acta physiol. scand. 11, 335.

Holmes, B. E. (1949a). Brit. J. Radiol. $22,487$.

Holmes, B. E. (1949 b). lst Int. Congr. Biochem. Abstr. p. 263.

Hull, W. \& Kirk, P. L. (1950a). J. gen. Physiol. 33, 325.

Hull, W. \& Kirk, P. L. (1950 b). J. gen. Physiol. 33, 335.

Hull, W. \& Kirk, P. L. (1950 c). J. gen. Physiol. 33, 343.

Jeener, R. (1949 a). Nature, Lond., 163, 837.

Jeener, R. (1949 b). Bull. Soc. Chim. biol., Paris, 31, 731.

Jeener, R. \& Szafarz, D. (1950a). Experientia, 6, 59.

Jeener, R. \& Szafarz, D. (1950 b). Arch. Biochem. 26, 54.
Juni, E., Kamen, M. D. \& Spiegelman, S. (1948). Arch. Biochem. 18, 387.

McCarter, J. A. \& Steljes, E. L. (1948). Canad. J. Res. E, 26, 333.

Mann, W. \& Gruschow, J. (1949). Proc. Soc. exp. Biol., N.Y., 71, 658.

Marshak, A. \& Calvet, F. (1949). J. cell comp. Physiol. 34, 451.

Mathison, G. C. (1909). Biochem. J. 4, 233.

Plimmer, R. H. A. \& Bayliss, W. M. (1906). J. Physiol. 33, 439.

Schmidt, G. \& Thannhauser, S. J. (1945). J. biol. Chem. 161, 83.

Schneider, W. C. (1945). J. biol. Chem. 161, 293.

Schneider, W. C. (1946). J. biol. Chem. 164, 747.

\title{
The Hexokinase Activity of Animal Tumours
}

\author{
By E. BOYLAND, G. C. L. GOSS AND H. G. WILLIAMS-ASHMAN \\ The Chester Beatty Research Institute of the Royal Cancer Hospital, London, S.W. 3
}

(Received 16 January 1951)

Slices of normal and tumour tissue which convert glucose to lactic acid rapidly (Warburg, 1930) have but little action on hexosediphosphate (Boyland \& Boyland, 1938). This difference is probably due to the fact that hexosediphosphate cannot diffuse into the tissue cells, but it was interpreted as an indication of non-phosphorylating glycolysis in tissues (Needham \& Lehmann; 1937). The demonstration of glycolysis of glucose, fructose and hexosediphosphate by fortified tumour extracts at the same rate as glycolysis in tumour slices (Boyland, Boyland \& Greville, 1937) indicated that glycolysis in tumours involved phosphorylation. No positive evidence of a glycolytic system in tumour tissue differing from that of other tissues has been put forward and enzymes of the normal glycolytic cycle have been found in tumour tissue. Meyerhof \& Wilson (1949) showed that glycolysis in tissue extracts is dependent on the ratio of phosphorylating and dephosphorylating enzymes present, and that tumour extracts contain excessive amounts of adenosinetriphosphatase (ATP-ase) relative to the hexokinase content.

The facts presented in this paper show that the hexokinase activity of certain rat tumours is sufficiently great to allow all the glucose used in anaerobic glycolysis of the tumour slices to pass through the stage of the hexokinase reaction. Some properties of the hexokinase of various rat and mouse tumours have also been investigated.

\section{METHODS}

Preparation of homogenates. The animals were killed by a blow on the head, the tumour removed and necrotic material dissected away as quickly as possible. The tissue was then

Biochem. 1951, 49 allowed to cool on ice for $10 \mathrm{~min}$. A portion (2-3 g.) was chopped with scissors, weighed and immediately added to an all glass homogenizer (Potter \& Elvehjem, 1936) and homogenized with 7 vol. of ice-cold $0.002 \%$ glucose. The resulting homogenate was strained through a wisp of glass-wool to remove fibrous strands.

Preparation of acetone powders. The tumour was removed immediately after the animal was killed, dissected free of necrotic material and allowed to cool on ice for $10 \mathrm{~min}$. The tissue was then homogenized in a Waring blender with 5 vol. cold acetone $\left(-5^{\circ}\right)$ for $2-3 \mathrm{~min}$. at $2^{\circ}$. The solid material was filtered off on a Büchner funnel and washed at least five times with cold acetone without allowing the filter cake to crack. It was then dried in a vacuum desiccator over $\mathrm{CaCl}_{2}$. The dry powder, if kept in vacuo at $2^{\circ}$, retained its hexokinase activity for at least 1 month. Aqueous extracts of the acetone powders were prepared by triturating with 10 vol. of icecold glass-distilled water and then centrifuging at approx. $2000 \mathrm{~g}$ for $15 \mathrm{~min}$. at $2^{\circ}$. The resulting supernatant fluid, after being passed through a wisp of glass-wool, was used for determination of the hexokinase activity.

Estimation of hexolinase activity. (a) In homogenates. The reaction was carried out in open test tubes at $38^{\circ}$. To each tube was added $0.50 \mathrm{ml}$. buffer; $0.10 \mathrm{ml}$. $0.2 \mathrm{M}-\mathrm{MgCl}_{2}$; $0.10 \mathrm{ml} .1 .5 \%$ glucose and $0.50 \mathrm{ml}$. water and/or additions. Freshly prepared homogenate $(1.00 \mathrm{ml}$.) was then added followed by $0.30 \mathrm{ml}$. M-KF (the fluoride was added after the homogenate had been added to the Mg-containing buffer mixture in order to minimize precipitation of $\mathrm{MgF}_{2}$ ). The tubes were then incubated at $38^{\circ}$ for $5 \mathrm{~min}$. and the reaction started by the addition of $0.50 \mathrm{ml}$. adenosinetriphosphate (ATP) solution (containing approx. $2 \mathrm{mg}$. acid-labile P). Duplicate tubes were removed immediately after the addition of the ATP in order to give values for the initial glucose concentration. The other tubes were incubated at $38^{\circ}$, while being shaken at the rate of $120 \mathrm{cyc}$./min., for $10-20 \mathrm{~min}$. The reaction mixtures were deproteinized by the addition of successive equal volumes of $0.3 \mathrm{~N}-\mathrm{Ba}(\mathrm{OH})_{2}$ and $5 \% \mathrm{ZnSO}_{4}$; 
after mixing and filtration, glucose was estimated in the filtrates either by the method of Nelson (1944) or that of Somogyi (1939). The hexokinase activity was expressed in terms of $\mu \mathrm{mol}$. glucose used/g. dry wt. of tissue/min. The dry weights of the homogenates were determined by heating to constant weight in an oven at $110^{\circ}$.

(b) In acetone powder extracts. The activity was determined by the manometric method of Colowick \& Kalckar (1943), the reactions being carried out in conventional Warburg flasks. The transfer of $1 \mathrm{~mol}$. of phosphate from ATP to glucose results in the liberation of 1 acid equiv. The main compartment of the vessels contained $1.00 \mathrm{ml} . \mathrm{M}-\mathrm{NaHCO}_{3}$; $0.02 \mathrm{M}-\mathrm{MgCl}_{2} ; 0.10 \mathrm{ml}$. sugar solution; $0.20 \mathrm{ml}$. $\mathrm{M}-\mathrm{KF}$ and the volume made up to $2 \cdot 20 \mathrm{ml}$. with enzyme, water and additions. The side arm contained $0.10 \mathrm{ml}$. $\mathrm{NaHCO}_{3}$; $0.02 \mathrm{M}-\mathrm{MgCl}_{2}$ and $0.20 \mathrm{ml}$. ATP (containing approx. $1 \mathrm{mg}$. acid-labile $\mathrm{P}$ in most experiments). The gas phase was $95 \%$ $\mathrm{N}_{2}-5 \% \quad \mathrm{CO}_{2}$. The bicarbonate concentration varied in different experiments, and is recorded under the relevant protocols. After $10 \mathrm{~min}$. equilibration at $38^{\circ}$ the contents of the side arm were tipped into the main compartment and the gas evolution measured at $5 \mathrm{~min}$. intervals for the next 30-60 min. Blanks containing all the reactants except the sugar were run in order to give values for the gas exchange which occurred on tipping the ATP solution into the main compartment and also for the small ATP-ase activity of some of the extracts. Unless otherwise stated, all figures recorded are corrected for ATP-ase activity (in cases where they are not, the $\mathrm{CO}_{2}$ evolution for the first $10 \mathrm{~min}$. after tipping was ignored).

Reagents. ATP, hexosediphosphate (HDP) and cozymase (CoI) were obtained from Schwarz Ltd. Methylbis(2chloroethyl)amine was obtained from the Ministry of Supply. Samples of $N N$-di(2-chloroethyl)- $\beta$-naphthylamine; 2:4:6tris(ethyleneimino)-s-triazine and butadiene diepoxide were kindly donated by Dr W. C. J. Ross. D-Fructose was obtained from Hofmann-La Roche Ltd. and recrystallized from ethanol. D-Galactose was obtained from Thomas Kerfoot Ltd., D-mannose and D-glucose from British Drug Houses Ltd.

\section{The hexokinase activity of freshly prepared tumour homogenates}

Hexokinase activity was demonstrated in the presence of the following buffers: $0.025 \mathrm{M}$-sodium

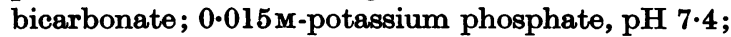
0.08 M-tris(hydroxymethyl)aminomethane, $\mathrm{pH} \mathrm{7.6}$ and tris(hydroxymethyl)aminoethane, $\mathrm{pH} 7 \cdot 6$. In the experiments performed in the presence of sodium bicarbonate the gas phase was $95 \% \mathrm{~N}_{2}-5 \%$ $\mathrm{CO}_{2}$, while with the other buffers used the gas phase was air. Experiments carried out in the presence of tris(hydroxymethyl)aminomethane and also phos- phate buffers showed that no glucose was used over an initial $15 \mathrm{~min}$. period when ATP was omitted from the reaction mixture.

With homogenates of Walker 256 carcinoma prepared from 8- to 10-day-old tumours the hexokinase activity in phosphate and tris(hydroxymethyl)aminomethane buffers varied from 13 to $25 \mu \mathrm{mol}$./g./ min. Homogenates of the necrotic cores of older tumours were devoid of hexokinase activity. With fresh tumour homogenates the reaction rate was proportional to the amount of tissue added over the range of approx. 5-25 mg. dry weight per reaction mixture. Maximal rates of reaction were observed with a final ATP concentration of $0.01 \mathrm{M}$ (if the ATP concentration was raised to $0.03 \mathrm{M}$ the rate was slightly diminished, possibly due to impurities in the ATP preparations used). The hexokinase activity with $0.01 \mathrm{M}$-ATP and $1.5 \mathrm{mg}$. glucose per reaction mixture was linear with time for at least $15 \mathrm{~min}$. The experiments summarized in Table 1 show that in the presence of bicarbonate buffer the addition of potassium ions had little influence on the hexokinase activity.

\section{Table 1. Influence of $\mathrm{KCl}$ on the hexokinase activity of Walker 256 carcinoma homogenate}

$\left(0.01 \mathrm{M}-\mathrm{MgCl}_{2} ; \quad 0.025 \mathrm{M}-\mathrm{NaHCO}_{3} ; 0.05 \mathrm{M}-\mathrm{NaF} ; 0.009 \mathrm{M}-\right.$ ATP. Gas phase: $95 \% \mathrm{~N}_{2}-5 \% \mathrm{CO}_{2}$.)

$\begin{array}{cc}\begin{array}{c}\text { Concentration } \\ \text { of added }\end{array} & \begin{array}{c}\text { Hexokinase activity } \\ \text { ( } \mu \text { mol. glucose } \\ \text { utilized } / \text { g./min.) }\end{array} \\ 0.0013 & 7 \cdot 1 \\ 0.0076 & 7 \cdot 5 \\ 0.014 & 8 \cdot 0 \\ 0.026 & 7 \cdot 9 \\ 0.051 & 8 \cdot 0 \\ 0.100 & 7 \cdot 4\end{array}$

The influence of the in vitro addition of a number of substances on the hexokinase activity of freshly prepared homogenates of Walker 256 carcinoma is shown in Table 2. The degree of inhibition found with methylbis(2-chlorethyl)amine and protoanemonin is similar to that observed with yeast hexokinase by Dixon \& Needham (1946). Ethyl carbamate, without influence on the tumour hexokinase when added in vitro, was also devoid of significant influence on the hexokinase activity of Walker 256 carcinoma when administered in vivo. Six rats were implanted with

Table 2. Inhibition of the hexokinase activity of freshly prepared homogenates of Walker 256 carcinoma

(Values shown are percentage inhibition.)

\begin{tabular}{|c|c|c|c|c|c|c|}
\hline Inhibitor concentration ( $\mathbf{M}) \ldots$ & ... & 0.0006 & 0.0012 & 0.0025 & 0.005 & $0 \cdot 01$ \\
\hline Choline chloride & & - & - & 0 & 0 & 0 \\
\hline Methyl-bis(2-chloroethyl)amine & & - & 42 & 58 & 75 & - \\
\hline Protoanemonin (vinylacrylolactone) & & 61 & 78 & 100 & 100 & - \\
\hline Ethyl carbamate & & - & - & $\overline{-1}$ & - & $\mathbf{0}$ \\
\hline Amidone (6-dimethylamino-4:4'-diphe & heptan-3- & - & 16 & 19 & 17 & - \\
\hline
\end{tabular}
one hydrochloride) 
the tumour and pair-fed on a vitamin-supplemented diet containing $5 \%$ protein. On the fifth day after implantation three animals were injected with $500 \mathrm{mg}$. ethyl carbamate $/ \mathrm{kg}$. while the controls were injected with water. The same doses were given daily for the following 4 days. The tumours were then removed from the animals and the hexokinase activity determined in phosphate buffer. No significant difference between the activity of the ethyl carbamate-treated animals and that of the controls was observed, despite the fact that the tumours of the former group were much smaller.

Homogenates of Jensen rat sarcoma exhibited the same order of hexokinase activity as those of Walker 256 carcinoma. One sample of Rous tumour (removed from the bird 28 days after inoculation of the virus) had a hexokinase activity of $13 \cdot 4 \mu \mathrm{mol}$. glucose utilized/g./min.

\section{The hexokinase activity of aqueous extracts of rat and mouse tumour acetone powders}

Rapid phosphorylation of $\mathbf{D}$-glucose was observed in the presence of extracts prepared from Walker 256 carcinoma, Jensen rat sarcoma, S37 mouse sarcoma and Crocker 180 sarcoma. The ATP-ase activity of such preparations was usually very small, and was never greater than $15 \%$ of the hexokinase activity. In the presence of glucose without ATP, no gas output whatsoever was observed. Hexosediphosphate (final concentration $0.3 \%$ ) gave rise to a carbon dioxide output no greater than that observed with ATP alone, hence the results obtained appeared to be uncomplicated by gas-producing reactions occurring past the phosphohexokinase stage. The hexokinase activity was proportional to the amount of enzyme solution over a fairly wide range $(0.20-0.70 \mathrm{ml}$. of a $1: 20$ extract/vessel). Most experiments were performed with 0.4 or $0.5 \mathrm{ml}$. of enzyme solution in each flask.

In one experiment it was observed that $0.5 \mathrm{ml}$. of a 1:30 aqueous extract of an acetone powder of Rous tumour exhibited a small but definite hexokinase activity. However, the high viscosity of such extracts make them unsuitable for hexokinase determination.
D-Fructose and D-mannose, but not D-galactose, were also phosphorylated by the enzyme. The relative rates of reaction in the presence of 2 and $50 \mu \mathrm{mol}$. of glucose and fructose (final concentrations of 0.008 and $0.02 \mathrm{M}$, respectively) with extracts prepared from different tumours is shown in Table 3. Over an initial $10 \mathrm{~min}$. period the rate with $2 \mu \mathrm{mol}$. glucose varied between 85 and $100 \%$ of that in the presence of $50 \mu \mathrm{mol}$. glucose. Fig. 1 shows that the rate of reaction with $2 \mu \mathrm{mol}$. glucose paralleled that with $50 \mu \mathrm{mol}$. glucose until most of

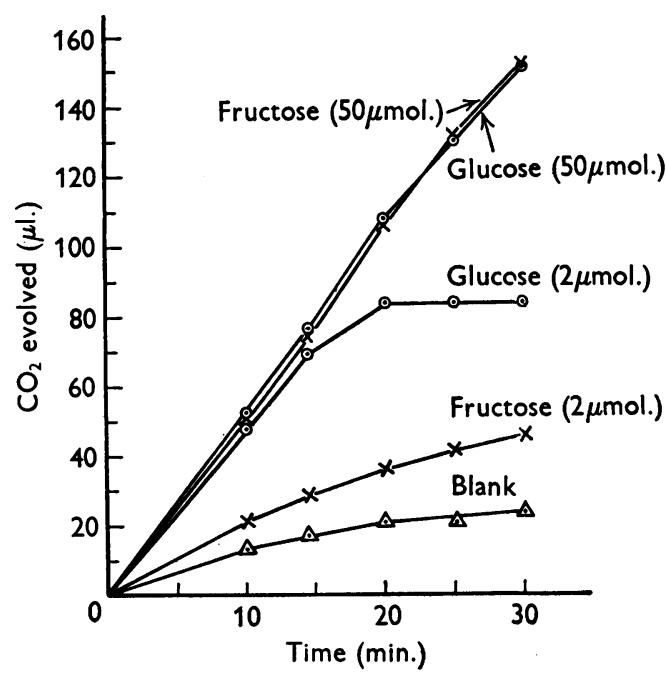

Fig. 1. Phosphorylation of glucose and fructose by Crocker 180 mouse tumour hexokinase.

the substrate had been exhausted. When $50 \mu \mathrm{mol}$. fructose were added per vessel, the hexokinase activity varied between 72 and $96 \%$ of that in the presence of $50 \mu \mathrm{mol}$. glucose, but with $2 \mu \mathrm{mol}$. fructose per vessel, the reaction rate varied between 3 and $21 \%$ of that in the presence of $50 \mu \mathrm{mol}$. fructose. The greater affinity of glucose as opposed to fructose for the enzyme is similar to that observed with tumour homogenates by Meyerhof \& Wilson (1949) and with

\section{Table 3. Phosphorylation of glucose and fructose by hexokinases of various rat and mouse tumours}

(All experiments carried out with $0.40 \mathrm{ml}$. 1:20 aqueous extract of acetone powder. Total volume of reaction mixture $=$ $2.50 \mathrm{ml}$.)

$\begin{array}{lcc} & \begin{array}{c}\text { Concn. of } \\ \text { NaHCO }\end{array} & \\ \text { in medium } & \\ \text { Tumour } & (\mathrm{M}) & \mathrm{pH}^{*} \\ \text { rcoma } & \mathbf{0 . 0 2 6 5} & \mathbf{7 \cdot 6 5} \\ \text { carcinoma } & \mathbf{0 . 0 4 2} & \mathbf{7 \cdot 8 3} \\ \text { morcinoma } & \mathbf{0 . 0 4 2} & \mathbf{7 \cdot 8 3} \\ \text { mouse carcinoma } & \mathbf{0 . 0 4 2} & \mathbf{7 . 8 3}\end{array}$

\begin{tabular}{|c|c|c|c|}
\hline \multirow{2}{*}{$\begin{array}{l}\text { Hexokinase } \\
\text { activity with } \\
50 \mu \mathrm{mol} \text {. } \\
\text { glucose/flask }\end{array}$} & \multicolumn{3}{|c|}{$\begin{array}{c}\text { Relative rates }(50 \mu \mathrm{mol} \text {. glucose }=100) \\
\text { in presence of }\end{array}$} \\
\hline & $\begin{array}{l}2 \mu \mathrm{mol} . \\
\text { glucose }\end{array}$ & $\begin{array}{l}50 \mu \mathrm{mol} . \\
\text { fructose }\end{array}$ & $\begin{array}{l}2 \mu \mathrm{mol} . \\
\text { fructose }\end{array}$ \\
\hline $\begin{array}{l}39 \cdot 0 \\
15 \cdot 0 \\
33 \cdot 5 \\
38 \cdot 5\end{array}$ & $\begin{array}{r}85 \\
100 \\
91 \\
87\end{array}$ & $\begin{array}{l}72 \\
90 \\
96\end{array}$ & $\begin{array}{r}3 \\
10 \\
21 \\
17\end{array}$ \\
\hline
\end{tabular}

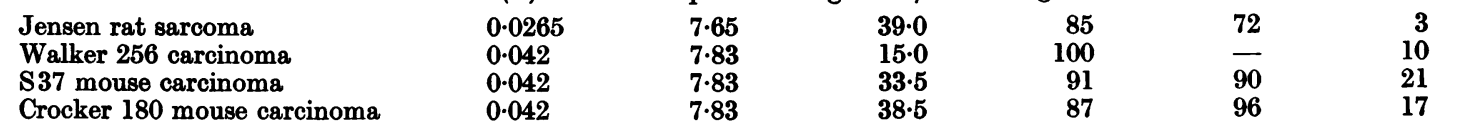

* At $37^{\circ}$, calculated from $\mathrm{NaHCO}_{3}$ concentration in equilibrium with $95 \% \mathrm{~N}_{2}-5 \% \mathrm{CO}_{2}$.

$\uparrow \mathrm{CO}_{2}(\mu \mathrm{l}$.) evolved in 10 min. after tipping ATP, corrected for ATP-ase activity. 
brain acetone powder extracts by Wiebelhaus \& Lardy (1949). Extracts of Jensen rat sarcoma phosphorylated D-mannose at about $90 \%$ the rate of glucose (final concentration of both sugars $0.02 \mathrm{M}$ ).

The hexokinase activity of Jensen rat sarcoma acetone powder extracts was not much increased by the addition of potassium ions. Thus, in a system containing no potassium salts, the addition of $0.08 \mathrm{M}$-potassium fluoride in place of $0.08 \mathrm{M}$-sodium fluoride enhanced the hexokinase activity some $20 \%$ (the ATP-ase activity was unaltered), but did not significantly affect the shape of the carbon dioxide output curve over the first $30 \mathrm{~min}$.

The influence of the in vitro addition of a number of substances on the hexokinase activity of aqueous extracts of Jensen rat sarcoma acetone powder is shown in Table 4. Certain of the compounds used

\section{Table 4. Inhibition of tumour hexokinase}

\begin{tabular}{|c|c|c|}
\hline Effector & $\begin{array}{l}\text { Concentration } \\
\text { (M) }\end{array}$ & $\begin{array}{c}\text { Inhibition } \\
(\%)\end{array}$ \\
\hline Ethyl carbamate & 0.027 & 0 \\
\hline Ethyl $N$-phenylcarbamate* & 0.0024 & 0 \\
\hline Methyl-bis(2-chloroethyl)amine $\dagger$ & 0.004 & 62 \\
\hline $\begin{array}{l}N N \text {-Bis(2-chloroethyl)- } \beta \text { - } \\
\text { naphthylamine* }\end{array}$ & 0.0002 & 0 \\
\hline $\begin{array}{l}\text { 2:4:6-Tris(ethyleneimino)-s- } \\
\text { triazine }\end{array}$ & 0.0003 & $\mathbf{0}$ \\
\hline Phlorrhizin & 0.009 & $\mathbf{0}$ \\
\hline Butadiene diepoxide & & 15 \\
\hline $\mathrm{CuSO}_{4}$ & 0.00005 & 66 \\
\hline $\mathrm{CoCl}_{2}$. & 0.0001 & 12 \\
\hline Suramin $\ddagger$ & 0.00008 & 43 \\
\hline $\begin{array}{l}\text { Amidone (6-dimethylamino- } \\
\text { 4:4'-diphenylheptan-3-one } \\
\text { hydrochloride) }\end{array}$ & 0.0028 & $\mathbf{0}$ \\
\hline \multicolumn{3}{|c|}{$\begin{array}{l}\text { * Dissolved in ethylene glycol monoethyl ether. } \\
\dagger \text { Corrected for hydrolysis; compound added to flasks } \\
\text { immediately after solution. } \\
\ddagger \text { Symmetrical urea of the sodium salt of } m \text {-benzoyl- } \\
m \text {-amino-p-methylbenzoyl-1-aminonaphthalene-4:6:8-trisul- } \\
\text { phonic acid. }\end{array}$} \\
\hline
\end{tabular}

Final concentration of bicarbonate buffer $0.0265 \mathrm{M}$.

were but sparingly soluble in water, and were added to the flasks in $0.10 \mathrm{ml}$. ethylene glycol monoethyl ether (EGEE), the appropriate controls being run in each case. Other experiments demonstrated that this concentration of EGEE was devoid of significant influence on the hexokinase activity.

\section{DISCUSSION}

It is of interest to compare the observed rates of hexokinase activity in tumour homogenates with the known glycolytic rates of slices of such tumours. Since each molecule of glucose gives rise to $2 \mathrm{~mol}$. of lactic acid, the hexokinase activities expressed in terms of $\mu \mathrm{mol}$. glucose utilized/g. dry wt./min. must be multiplied by $2 \times 22.4 \times 60 / 1000=26.88$ to be converted into equivalent $Q_{\mathrm{Co}_{2}}^{\mathrm{N}}$ values in $\mu \mathrm{l} . / \mathrm{mg}$. dry wt./hr. Thus the $Q_{\mathrm{co}_{2}}^{\mathbb{N}_{2}}$ values equivalent to the hexokinase activity of Walker 256 carcinoma and Jensen rat sarcoma varied between 35 and 67 . The maximal $Q \mathrm{CO}_{2}^{\mathrm{N}}$ for slices of these tumours at $37^{\circ}$. is approximately 35, so that the hexokinase activity appears to be at least sufficient to allow all the glucose utilized to pass through this reaction. Whether hexokinase is a possible rate limiting factor in tumour glycolysis, however, can only be decided after further experiments. In this study no measurements of the possible dephosphorylation of hexose phosphates under the conditions of the hexokinase assay were made, and it is possible that the hexokinase activity values observed are too low since they are computed from estimations of glucose utilization. Nevertheless, assuming that the hexokinase activities are not grossly in error, and that the enzyme is maximally active in slices, it would seem that the hexokinase content of tumours resembles that of aldolase (Warburg \& Christian, 1943; Sibley \& Lehninger, 1949) in being sufficient to allow .a glycolytic rate not greater than 2-3 times that observed in tumour slices. Other glycolytic enzymes, e.g. triosephosphate isomerase (Oesper \& Meyerhof, 1950) are known to be present in far greater excess in animal tumours.

The data given in Table 4 on the inhibition of tumour hexokinase by a number of mitotic poisons would suggest that, although nitrogen mustard is an inhibitor of hexokinase, this is not an essential character of mitotic poisons. The other radiomimetic mitotic poisons tested in this experiment (ethyl carbamate, $N N$-bis(chloroethyl)- $\beta$-naphthylamine, 2:4:6-tris(ethyleneimino)-s-triazine and butadiene diepoxide) are all substances which react relatively slowly (cf. Ross, 1950) so that chemical reaction between the inhibitor and enzyme would be negligible under the experimental conditions. Those experiments, therefore, give no evidence on the possible relation between mitotic inhibition and poisoning of hexokinase.

\section{SUMMARY}

1. The hexokinase activity of animal tumours is sufficient to account for all the glucose used in the anaerobic glycolysis of tumour slices passing through the hexokinase reaction.

2. The tumour enzyme phosphorylated glucose and mannose readily. For optimum phosphorylation of fructose a higher concentration was required. Galactose was not phosphorylated.

3. The enzyme was inhibited in vitro by methylbis(2-chloroethyl)amine but not by other radiomimetic mitotic poisons which react more slowly.

This investigation has been supported by grants made to the Royal Cancer Hospital by the British Empire Cancer Campaign, the Jane Coffin Childs Memorial Fund for Medical Research, the Anna Fuller Fund, and the Division of Research Grants of the U.S. Public Health Service. One of us (G. C.L. G.) is indebted to the Department of Veteran Affairs (Canada), the Beaver Club and the British Council for grants. 


\title{
REFERENCES
}

Boyland, E. \& Boyland, M. E. (1938). Biochem. J. 32, 321.

Boyland, E., Boyland, M. E. \& Greville, G. D. (1937). Biochem. J. 31, 461.

Colowick, S. P. \& Kalckar, H. M. (1943). J. biol. Chem. 148, 117.

Dixon, M. \& Needham, D. M. (1946). Nature, Lond., 158, 432.

Meyerhof, O. \& Wilson, J. (1949). Aroh. Biochem. 21, 22.

Needham, J. \& Lehmann, H. (1937). Biochem. J. 31, 1210.

Nelson, N. (1944). J. biol. Chem. 153, 375.

Oesper, P. \& Meyerhof, O. (1950). Arch. Biochem. 27, 223.
Potter, V. R. \& Elvehjem, C. A. (1936). J. biol. Chem. 114, 495.

Ross, W. C. J. (1950). J. chem. Soc. p. 2257.

Sibley, J. \& Lehninger, A. L. (1949). J. Nat. Cancer Inst. 9, 303.

Somogyi, M. (1939). J. biol. Chem. 86, 655.

Warburg, O. (1930). The Metabolism of Tumours (translated by Dickens, F.). London: Constable.

Warburg, O. \& Christian, W. (1943). Biochem. Z. 314, 399.

Wiebelhaus, V. D. \& Lardy, H. A. (1949). Arch. Biochem. 21, 321.

\section{The Utilization of Non-protein Nitrogen in the Bovine Rumen}

\section{A QUALITATIVE AND QUANTITATIVE STUDY OF THE BREAKDOWN \\ OF CARBOHYDRATE WHICH ACCOMPANIES PROTEIN FORMATION IN BOVINE RUMEN CONTENTS DURING IN VITRO INCUBATION}

\author{
By MARY L. McNAUGHT \\ The Hannah Dairy Research Institute, Kirkhill, Ayr
}

(Received 23 January 1951)

In an earlier paper of the present series Pearson \& Smith $(1943 a)$ showed that when fresh rumen contents were incubated in vitro both synthesis and hydrolysis of protein could readily occur, but that to obtain the prolific bacterial growth which results in protein synthesis predominating over protein hydrolysis, an ample supply of readily available carbohydrate was essential. It would appear probable, therefore, that the non-protein nitrogenous constituents of feeding stuffs may be of value in the rumen only when there is also an abundance of simple sugar or starch in the diet, and since the products commonly fed to ruminants contain many different types of carbohydrates and related compounds, it seemed important to determine to what extent protein synthesis predominated in rumen contents when a variety of different substances were made available as possible sources of energy for the bacteria. It was hoped also that the work would give information regarding the types of compound on which rumen micro-organisms can act. Pearson \& Smith (1943a) had already shown that when soluble starch, D-(+)-galactose, sucrose, maltose, lactose and D- $(+)$-glucose were added to rumen liquid during incubation in vitro, vigorous bacterial proliferation resulting in the predomination of protein synthesis occurred. The present communication describes the extension of that work to include other naturally occurring carbohydrates, such as arabinose and xylose, and also certain derivatives of carbohydrates. Several other substances including lower fatty acids, lactic acid and succinic acid have also been tested.
It is now well established that much of the carbohydrate in the diet of ruminating animals is fermented in the rumen to form various end products which include lower fatty acids, carbon dioxide and methane (Phillipson, 1947-8; Elsden \& Phillipson, 1948), but since the rumen is part of an open system from which these products can pass further along the alimentary tract or can be absorbed into the blood or be excreted in the breath, it is not easy to estimate in vivo the proportions in which these various substances are produced. It seemed possible, however, that by adapting the in vitro incubation technique of Pearson \& Smith (1943a) so that the gaseous products of fermentation could be collected and analysed, it would be possible to determine approximately, but with more accuracy than hitherto, the relative proportions in which the various end products were formed from different sugars, and how much of the utilized sugar could be accounted for by the end products. Since maltose and the pentoses arabinose and xylose are all known to occur as units of more complex carbohydrate molecules in vegetable products, these three carbohydrates were used in this quantitative section of the work.

The objects of the present investigation were first to find what types of compound could be utilized by the rumen bacteria to enable protein synthesis to predominate over protein hydrolysis, and secondly to determine the proportions in which the main end products of carbohydrate fermentation in rumen contents are formed, how much of the fermented carbohydrate can be accounted for by these pro- 